Reprod. Nutr. Dévelop., 1982, 22 (1 A), 81-91.

\title{
The effects of centrifugation, various synthetic media and temperature on the motility and vitality of human spermatozoa
}

\author{
Claudette JEULIN, Catherine SERRES, P. JOUANNET
}

Laboratoire d'Histologie-Embryologie-Cytogénétique, Centre Hospitalier, 94270 Kremlin-Bicêtre, France.

Summary. The influence of various technical procedures and diluent media upon human spermatozoa has been tested in vitro. The percentage and velocity of motile spermatozoa were measured objectively using laser Doppler velocimetry. Vitality was determined by fluorescent staining.

Centrifugation of semen (diluted $1: 1$ with Tyrode) at forces of 500, 800, 1800 and $2500 \times \mathrm{g}$ resulted in almost complete sedimentation of the spermatozoa. After resuspension in Tyrode's, spermatozoal motility was not changed significantly.

The percentages of motile spermatozoa (measured at $37^{\circ} \mathrm{C}$ ) in Tyrode's and $\mathrm{B}_{2}$ medium remained the same as those in seminal plasma throughout an 8-hr period of incubation at $20^{\circ} \mathrm{C}$, while those in Locke's and phosphate-buffered saline (PBS) were significantly lower. The instantaneous modal velocities $(\mathrm{Vc})$ of spermatozoa (also measured at $37^{\circ} \mathrm{C}$ ) in Locke's, Tyrode's and $\mathrm{B}_{2}$ were all significantly increased as compared to those observed in seminal plasma during incubation at $20^{\circ} \mathrm{C}$; spermatozoa in PBS showed a significantly reduced velocity compared to seminal plasma, but the difference was not significant. However, the rates of decline of the percentage of motile spermatozoa and of their velocities were indistinguishable in all four synthetic media and in the seminal plasma.

No significant change in vitality was observed in any medium during the 8-hr incubation period at $20^{\circ} \mathrm{C}$.

When spermatozoa were incubated at $37{ }^{\circ} \mathrm{C}$, rapid declines in both percentage motile and in velocity were observed with incubation periods lasting more than $4-h$. Subjecting the spermatozoa to a temperature of $4^{\circ} \mathrm{C}$ for 1 -h did not significantly change either of the motility parameters (measured at $37^{\circ} \mathrm{C}$ ), although prolonged exposure to $4^{\circ} \mathrm{C}$ did greatly reduce their motility and velocity percentages.

The decline in vitality was slow and uniform during incubation at either 4,20 or $37^{\circ} \mathrm{C}$ over periods of up to $10-\mathrm{hr}$, the best survival apparently being obtained at $20^{\circ} \mathrm{C}$ and the worst at $4{ }^{\circ} \mathrm{C}$, although there were no significant temperature differences at any time.

\section{Introduction.}

It is generally accepted that spermatozoa, in order to stand any chance of fertilizing eggs in vivo, must leave the environment of the seminal plasma within minutes following ejaculation and penetrate the cervical mucus (Tredway et al., 
1975). Consequently, in vitro tests designed to evaluate sperm function cannot purport to have any physiological significance if they concern simply ejaculated spermatozoa in seminal plasma. In vitro fertilization systems all use defined synthetic media which not only permit the survival and development of eggs but also the survival and capacitation of spermatozoa (Yanagimachi et al., 1976 ; Lopata et al., 1978; Overstreet et al., 1980). Indeed, the presence of seminal plasma in an in vitro system is known to inhibit sperm fertilizing ability (Kanvar et al., 1979). Seminal plasma is a complex, multiglandular secretion ; its incompletely known composition may vary both between and within individuals. Therefore, seminal plasma is not a good standard medium for testing the influence of any exogenous factors on spermatozoal motility and/or metabolism. Clearly, there is a need to evaluate the various synthetic media and to determine their effects upon the survival and physiology of spermatozoa. In addition to selecting the optimal media for carrying out such procedures as in vitro longevity testing or as sperm recovery, from men with retrograde ejaculation, for subsequent artificial insemination (AI), dilution, centrifugation and influence of incubation temperature must also be evaluated for their effects upon sperm motility, vitality and morphology.

Many such studies have been carried out in several species (bull: Bredderman and Foote, 1971 ; man: Harvey, 1960 ; Freund and Wiederman, 1966 ; Peterson and Freund, 1969), and while modifications in sperm parameters were often noted, precise quantification was often impossible due to the subjectivity of the techniques used. This is particularly true of measurements of sperm motility. The present study was designed to determine the influence of centrifugation and variations in the temperature and medium used for incubation upon the vitality and the objectively-determined motility of ejaculated human spermatozoa.

\section{Material and methods.}

Fifteen semen samples whose parameters all fell well within the normal ranges described by Eliasson, 1977, were obtained from volunteers (table 1). After liquefaction $(60 \mathrm{~min})$ the following parameters were measured for each sample.

TABLE 1

Semen sample parameters

\begin{tabular}{cccccccc}
\hline Experiment & $\begin{array}{c}\text { Spermatozoal } \\
\text { concentration } \\
\left(10^{6} / \mathrm{ml}\right)\end{array}$ & $\begin{array}{c}\text { Percentage } \\
\text { of } \\
\text { motile forms }\end{array}$ & $\begin{array}{c}\text { Characteristic } \\
\text { velocity } \\
\left(\mu \mathrm{m} \mathrm{s} \mathbf{s}^{-1}\right)\end{array}$ & $\begin{array}{c}\text { Percentage } \\
\text { of vital forms }\end{array}$ & $\begin{array}{c}\text { Viscosity } \\
\text { (cp) }\end{array}$ & $\begin{array}{c}\text { Percentage } \\
\text { of } \\
\text { normal forms }\end{array}$ \\
\hline $\mathrm{N}^{\circ}$ I & $126.1 \pm 45.3$ & $77.2 \pm 11.7$ & $59.4 \pm 9.8$ & $78.3 \pm 10.1$ & $4.6 \pm 1.3$ & $55.0 \pm 17.5$ \\
$\mathrm{~N}^{\circ}$ II & $109.6 \pm 48.4$ & $71.4 \pm 21.6$ & $64.0 \pm 12.6$ & $76.9 \pm 13.1$ & $4.5 \pm 3.7$ & $61.2 \pm 9.6$ \\
$\mathrm{~N}^{\circ}$ III & $158.0 \pm 105.2$ & $75.2 \pm 16.8$ & $69.2 \pm 12$ & $79.0 \pm 10.2$ & $4.5 \pm 2.1$ & $60.6 \pm 9.2$ \\
\hline
\end{tabular}

Mean values $( \pm S D)$ of the various parameters of the groups of 5 ejaculates used in each of the 3 experiments. 
1) The sperm count was carried out with an hemocytometer. A minimum of 400 spermatozoa were counted for each sample (Laplanche, 1978).

2) The percentage of vital cells (vitality) was measured by scoring 200 spermatozoa stained with Acridine Orange and Ethidium Bromide (Festenstein et al., 1978) : $50 \mu$ l of semen were mixed with $10 \mu$ l of Acridine Orange $(0.25 \mathrm{~g} / \mathrm{ml}$ ) and $50 \mu \mathrm{l}$ of Ethidium Bromide $(4.5 \mu \mathrm{g} / \mathrm{ml})$. The observation was made immediately after staining using a fluorescence microscope (Epi illumination, Ploemorthoplan Leitz, Hb0 $200 \mathrm{~W}$ lamp, BG12 excitation filter, $530 \mathrm{~nm}$ blocking filter). This technique permits an easy distinction between vital (green) and presumably dead (red) spermatozoa.

3) Viscosity was evaluated by measuring the time necessary for $1 \mathrm{ml}$ of semen to run out a calibrated capillary tube in comparison with oils of known viscosity (Allouch, 1980).

4) Sperm motility was measured objectively at $37^{\circ} \mathrm{C}$ using a method based upon laser Doppler velocimetry (LDV : Dubois et al., 1975). Parameters considered were the percentage of motile cells and the mode of instantaneous velocity distribution, the " characteristic velocity » (Vc).

5) Morphology was evaluated according to the classification of David et al. 1975).

Four synthetic media were investigated: phosphate-buffered saline (PBS), Locke's solution, Tyrode's solution and $B_{2}$ medium (Ménézo, 1979, INRA : API system). The compositions of the media are given in table 2 . Five semen samples were used for each of the three experiments (see below) ; their mean parameters are given in table 1.

TABLE 2

Composition of the various media $(\mathrm{pH}=7.5)$

\begin{tabular}{|c|c|c|c|c|}
\hline & PBS & Locke's S. & Tyrode's S. & $B_{2}$ (INRA)'s S. \\
\hline $\mathrm{NaCL}(\mathrm{mM})$ & 145 & 145 & 137 & 90 \\
\hline $\mathrm{Na} \mathrm{H}_{2} \mathrm{PO}_{4}, 2 \mathrm{H}_{2} \mathrm{O}(\mathrm{mM}) \ldots$ & 1.9 & - & 0.3 & - \\
\hline $\mathrm{Na}_{2}, \mathrm{HPO}_{4}, 12 \mathrm{H}_{2} \mathrm{O}(\mathrm{mM}) \ldots$ & & - & - & 0.4 \\
\hline $\mathrm{Kcl}(\mathrm{mM}) \ldots \ldots \ldots \ldots$ & & 5.6 & 2.7 & 11 \\
\hline $\mathrm{Na} \mathrm{HCO}_{3}(\mathrm{mM})$ & & 2.3 & 12 & 29.7 \\
\hline $\mathrm{Ca} \mathrm{Cl}_{2}, 2 \mathrm{H}_{2} \mathrm{O}(\mathrm{mM})$ & & 1.7 & 1.4 & - \\
\hline Glucose $(\mathrm{mM}) \ldots \ldots$ & & 14 & 5.5 & 7.0 \\
\hline $\mathrm{Mg} \mathrm{Cl}_{2}, 6 \mathrm{H}_{2} \mathrm{O}(\mathrm{mM})$ & & & & \\
\hline $\mathrm{Mg} \mathrm{SO}_{4}, 7 \mathrm{H}_{2} \mathrm{O}(\mathrm{mM})$ & & & & 0.8 \\
\hline $\mathrm{KH}_{2} \mathrm{PO}_{4}(\mathrm{mM}) \ldots \ldots$ & & & & 0.4 \\
\hline Sodium acetate $(\mathrm{mg} / 100 \mathrm{ml})$ & & & & 5 \\
\hline Calcium lactate $(\mathrm{mg} / 100 \mathrm{ml})$ & & & & 50 \\
\hline Sodium pyruvate $(\mathrm{mg} / 100 \mathrm{ml})$ & & & & 25 \\
\hline BSA $(\mathrm{mg} / 100 \mathrm{ml}) \ldots \ldots$ & & & & 1000 \\
\hline Vitamin C (mg/100 ml) .. & & & & 5 \\
\hline Tween $80(\mathrm{mg} / 100 \mathrm{ml})$ & & & & 5 \\
\hline Cholesterol $(\mathrm{mg} / 100 \mathrm{ml})$ & & & & 12.5 \\
\hline Penicillin (U) ......... & & & & 2500 \\
\hline Streptomycin (mg/100 ml) & & & & 4 \\
\hline Amino-acids (23) mg/ $100 \mathrm{ml}$ ) & & & & 134.8 \\
\hline Osmolarity mosm $/ \mathrm{kg}$ & 290 & 300 & 295 & 310 \\
\hline
\end{tabular}


Experiment $N^{\circ}$ 1: The effect of centrifugal forces. - Each of the 5 semen samples was diluted 1: 1 with Tyrode's solution then divided into four $\mathrm{I}-\mathrm{ml}$ aliquots. Each aliquot was centrifuged at room temperature for $10 \mathrm{~min}$ at either $500,800,1500$ or $2500 \times \mathrm{g}$. The number of spermatozoa remaining in the supernatant was counted. Pellets were resuspended in $1 \mathrm{ml}$ of fresh Tyrode's solution by gentle pipetting and vortex mixing. The percentage of motile spermatozoa, the characteristic velocity and the percentage of morphologically normal spermatozoa were measured in each sample before and after centrifugation.

Experiment $N^{\circ} 2$ : The influence of media on motility and vitality as a function of time. - Each of the 5 ejaculates was divided into five equal parts : one was retained as a control while the other 4 were each diluted $1: 1$ with one of the 4 media under test. After a $10 \mathrm{~min}$ centrifugation $(800 \times \mathrm{g})$ the supernatants were discarded and the pellets resuspended in the initial volume of fresh medium. All samples were kept at room temperature for $8 \mathrm{hrs}$. Motility and vitality parameters were measured after 2, 4,6 and $8 \mathrm{hrs}$ and expressed as a proportion of the initial value in seminal plasma.

Experiment $N^{\circ} 3:$ Influence of temperature on spermatozoon survival. - After 1 : 1 dilution of each, of the 5 semen samples with $B_{2}$ medium, the sample was centrifuged at $800 \times \mathrm{g}$ for $10 \mathrm{~min}$. Supernatants were discarded and the pellets resuspended in $\mathrm{B}_{2}$ by gentle pipetting and vortex mixing. Each sperm suspension was divided into 6 parts : Fractions I and $I I\left(0.5 \mathrm{ml}\right.$ each) were kept at $37^{\circ} \mathrm{C}$ and $20^{\circ} \mathrm{C}$, respectively ; Fractions III to $\mathrm{VI}\left(0.1 \mathrm{ml}\right.$ each) were maintained at $4{ }^{\circ} \mathrm{C}$ for $1,4,7$ and $10 \mathrm{hrs}$, respectively; each fraction was returned to room temperature 10 min before measurements were taken.

Statistical analysis. - Results of experiment $\mathrm{N}^{\circ} 1$ were analysed with Student's $t$-test. The results of experiment $\mathrm{N}^{\circ} 2$, giving the ratios of values measured after different times of incubation in synthetic media and at initial times in seminal plasma, were analysed with a linearity and a parallelism test (covariance analysis), analysis of variance and Student's $t$-test. Results of experiments $N^{\circ} 3$ were analysed with an analysis of variance and Student's $t$-test.

Results.

Experiment $N^{\circ} 1$ (table 3). - Centrifugation of human spermatozoa at 500, 800, 1800 or $2500 \times \mathrm{g}$ did not significantly reduce the percentage of motile spermatozoa. The characteristic velocity (Vc) was not modified except at $2500 \times \mathrm{g}$ when a weakly significant $(P<0.05)$ decrease was observed. There was also a small decrease in the percentage of vital spermatozoa after centrifugation at 500 and $800 \times \mathrm{g}$. Almost all the spermatozoa ( $\geq 98$ p. 100) were located in the pellet, and the proportion of spermatozoa remaining in the 
supernatant decreased with increasing centrifugal force. No significant modifications in the percentage of morphologically normal forms were observed.

TABLE 3

Effect of gravitation force on the percentage of motile, vital and morphologically normal forms of human spermatozoa and their $V c$ (Values $=$ mean $\pm \mathrm{SE}$ )

\begin{tabular}{|c|c|c|c|c|}
\hline & $500 \mathrm{~g}$ & $800 \mathrm{~g}$ & $1800 \mathrm{~g}$ & $2500 \mathrm{~g}$ \\
\hline $\begin{array}{l}\text { Motility (p. } 100) \\
R_{m}=\frac{\% \text { after }}{\% \text { before }}\end{array}$ & $0.92 \pm 0.19$ NS & $0.87 \pm 0.14$ NS & $0.98 \pm \underset{\text { NS }}{0.19}$ & $0.91 \pm 0.19$ \\
\hline $\begin{array}{l}\text { Velocity } \\
R_{V_{c}}=\frac{V_{c} \text { after }}{V_{c} \text { before }}\end{array}$ & $1.03 \pm 0.27$ NS & $1.00 \pm 0.07$ NS & $0.99 \pm 0.24$ NS & $\begin{array}{l}0.80 \pm 0.17 \\
p<0.05\end{array}$ \\
\hline $\begin{array}{l}\text { Vitality } \\
\mathrm{R}_{\mathrm{V}}=\frac{\% \text { after }}{\% \text { before }}\end{array}$ & $\begin{aligned} 0.86 \pm 0.06 \\
p<0.05\end{aligned}$ & $\begin{aligned} 0.88 \pm & 0.10 \\
p & <0.05\end{aligned}$ & $0.91 \pm 0.12$ NS & $0.90 \pm 0.11$ NS \\
\hline $\begin{array}{l}\text { Sperma to zoa } \\
\text { density in } \\
\text { supernatant } / \mathrm{ml}\end{array}$ & $2.3 \times 10^{6} \pm 0.9$ & $0.9 \times 10^{6} \pm 0.5$ & $0.4 \times 10^{6} \pm 0.3$ & $0.2 \times 10^{6} \pm 0.1$ \\
\hline $\begin{array}{l}\text { Morphology } \\
R_{M}=\frac{\text { nor. } \% \text { aft. }}{\text { nor. } \% \text { bef. }}\end{array}$ & 0.93 & 0.89 & 0.95 & 0.90 \\
\hline
\end{tabular}

Experiment $N^{\circ} 2$ : First step : dilution. - When human semen samples were diluted in Locke's, Tyrode's or $B_{2}$ there was no significant modification of the percentage of motile spermatozoa. In PBS, there was a $17 \mathrm{p}$. 100 relative diminution of motile spermatozoa $(P<0.02)$. The increase in $\mathrm{Vc}$.was significant $(P<0.001)$ in all four synthetic media, being greater in Locke's (37 p. 100) and Tyrode's (35 p. 100); than in $B_{2}$ and PBS (27 p. 100).

Second step: Incubation in media. - There were significant decreases in the percentage of motile spermatozoa with time (fig. 1a) in seminal plasma and in the four tested media. The decreases were linear over the 8-hour period of incubation in all cases $(P>0.05)$ and the graphs were parallel $(P>0.05)$. This evolution of motility was identical in seminal plasma, Tyrode's and $B_{2}$; but in PBS and Locke's the percentages of motile spermatozoa were significantly lower $(P<0.01)$ after all periods of incubation. There were decreases in $\mathrm{Vc}$ with time (fig. 1b); the evolution of $V_{c}$ was linear for all media $(P>0.05)$ and the graphs were parallel $(P>0.05)$. Vc was significantly higher at all times in Tyrode's, $\mathrm{B}_{2}$ 
and Locke's $(P<0.001)$ but not different in PBS as compared to its measurements in seminal plasma.
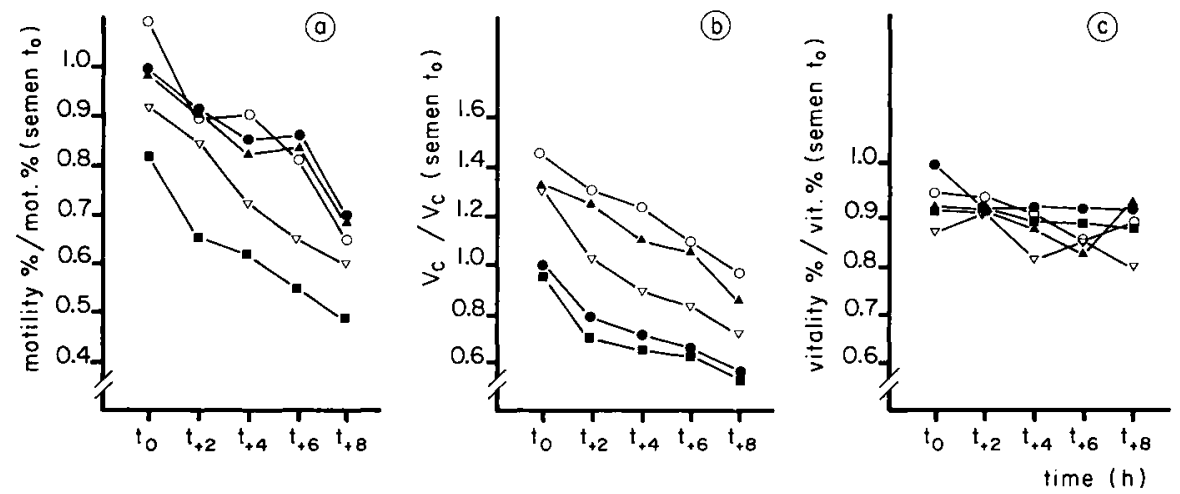

FIG. 1. - Human spermatozoa survival $\left(20^{\circ} \mathrm{C}\right)$ in seminal plasma

locke's solution

a) percentage of motile forms ; b) $\left.\mathrm{V}_{c} ; c\right)$ percentage of vital forms.

There was no modification in the vitality of spermatozoa during the period of incubation and there were no differences between the 5 media. Thus, such a difference in the evolution of motility and vitality might indicate that increasingly more spermatozoa, although vital, were immotile, probably due to the absence of essential substrates in the media. $\mathrm{B}_{2}$ medium, which permits optimal preservation of motility, was added to spermatozoa suspended in PBS after 2 and $4 \mathrm{hrs}$ of
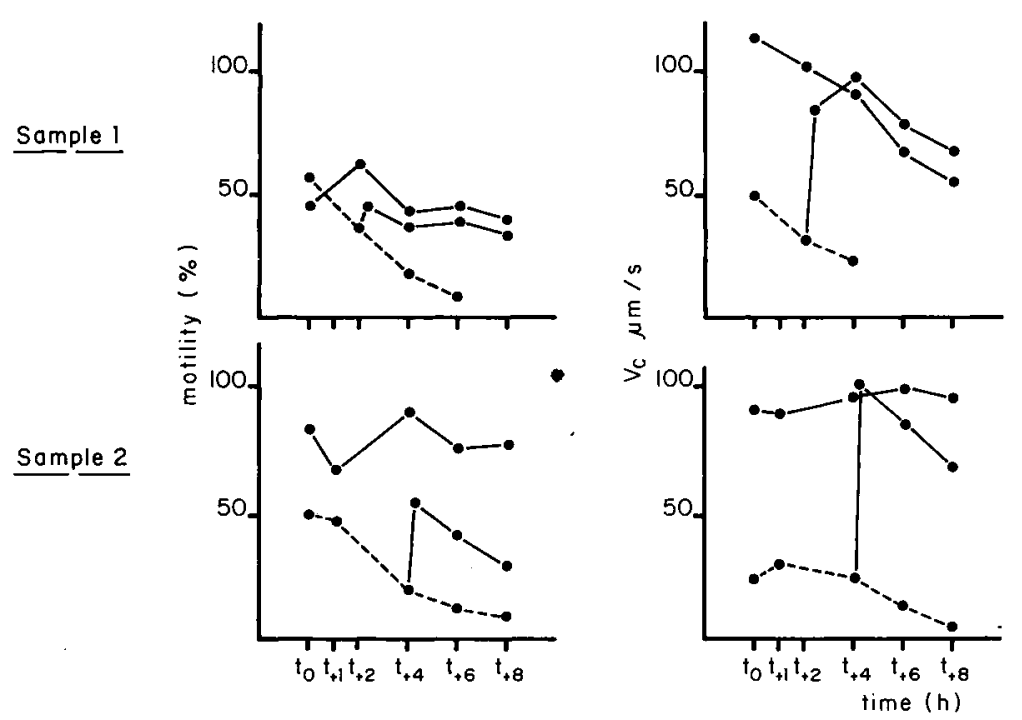

FIG. 2. - Two examples of mobilization of immotile forms of human spermatozoa by the addition of $B_{2}$ medium (-) after 2 or 4 hrs incubation in PBS - - ) 
incubation. In both cases, the percentages of motile spermatozoa and of Vc increased immediately and permanently (fig. 2), i.e. there was a "remobilization » of immotile spermatozoa.

Experiments $N^{\circ} 3:$ The influence of temperature. - There was no modification in' the percentage of motility when spermatozoa were maintained for one hour at 4, 20 or $37^{\circ} \mathrm{C}$ (fig. 3a). However, after 4 and $7 \mathrm{hrs,}$ the percentage of motile spermatozoa was significantly lower for those kept at $4{ }^{\circ} \mathrm{C}$ than for those maintained at 20 or $37{ }^{\circ} \mathrm{C}(\mathrm{P}<0.001)$. After incubation for 10 hrs at $4^{\circ} \mathrm{C}$ only a very few spermatozoa were still moving and there was also a marked decrease in the motility of those kept at $37^{\circ} \mathrm{C}$; the difference from the sample at $20^{\circ} \mathrm{C}$ was significant $(P<0.001)$. Vc was significantly increased after one hour of incubation in $\mathrm{B}_{2}$ at 4,20 or $37^{\circ} \mathrm{C}(P<0.001)$, its value being greater at $37^{\circ} \mathrm{C}$ than at 20 or $4{ }^{\circ} \mathrm{C}\left(37^{\circ} \mathrm{C}\right.$ vs $20^{\circ} \mathrm{C}: P<0.02 ; 37^{\circ} \mathrm{C}$ vs $\left.4{ }^{\circ} \mathrm{C}: P<0.001\right)$. The decline of $\mathrm{Vc}$ with time was rapid at $4{ }^{\circ} \mathrm{C}$ and the best temperature for maintaining velocity up to $10 \mathrm{hrs}$ appeared to be $20^{\circ} \mathrm{C}$. The decline in vitality was slow and regular with no significant differences between the three incubation temperatures.
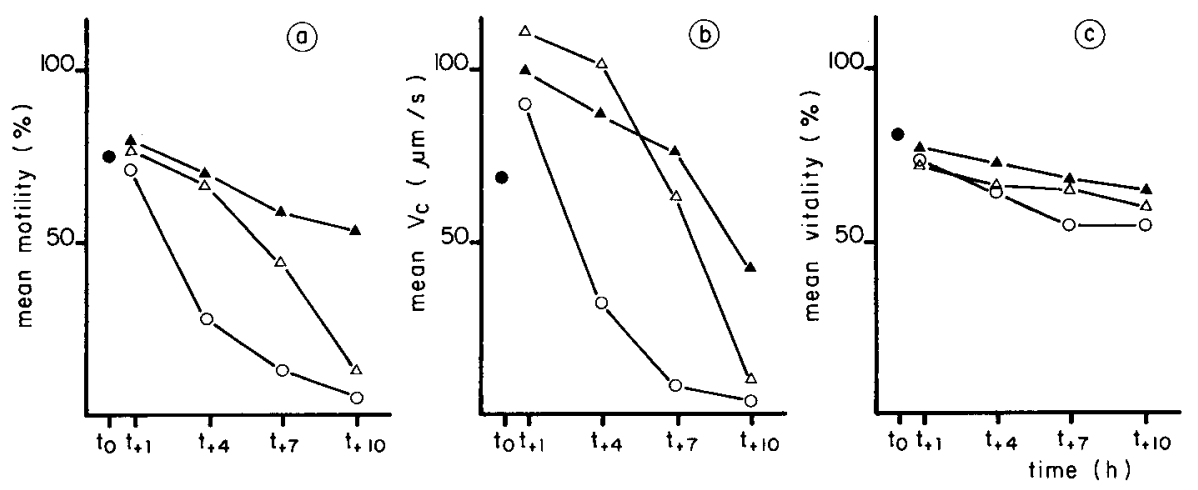

FIG. 3. - Human spermatozoa survival in $B_{2}$ medium at $4^{\circ} \mathrm{C}(0), 20^{\circ} \mathrm{C}(\boldsymbol{\Delta}), 37^{\circ} \mathrm{C}(\triangle)$.

a) mean percentage of motile forms; b) mean $\left.V_{c} ; c\right)$ mean percentage of vital forms $(\bullet)=$ values in seminal plasma at $\mathrm{t}_{0}$.

\section{Discussion.}

Whatever the purpose of studies on living spermatozoa, their different technical steps should have no or negligible influence on the spermatozoa. If changes are unavoidable, they should be specified and precisely evaluated. When human spermatozoa diluted in Tyrode's, are exposed to centrifugal forces of 500, $800,1800,2500 \times \mathrm{g}$ for periods of $10 \mathrm{~min}$, almost all the spermatozoa are concentrated in the pellet which shows no significant changes in cell motility percentage, velocity or morphology. Small reductions in the percentage of vital cells were observed after centrifugation at 500 or $800 \times \mathrm{g}$ but surprisingly not after exposure to higher centrifugal forces. One hypothesis could be that at lower 
speeds, the dead spermatozoa, which have a higher specific gravity than live spermatozoa (Benedict et al., 1967), were pelleted, while some vital (and motile) cells remained in the supernatant. Another hypothesis is that the pellet is less compact when lower centrifugal forces are used, allowing motile spermatozoa to swim into the supernatant during the time between the end of centrifugation and pipetting of the supernatant. Two and $1.0 \mathrm{p}$. 100 of spermatozoa remained in suspension after centrifugation at 500 and $800 \times \mathrm{g}$, respectively. Either $1800 \times \mathrm{g}$ or a longer period of centrifugation was necessary to obtain an optimum recovery of spermatozoa from suspension. The main problem encountered in the centrifugation of spermatozoa is to ensure a repeatably good sedimentation. The influence of seminal plasma viscosity probably explains the variations observed between different ejaculates. Such variations could be minimized by a previous dilution of the semen. Another presumable effect of decreased viscosity could be that a $1: 1$ dilution (PBS excepted) does not modify the percentage of motile spermatozoa but does increase their velocity.

There is a progressive and linear decline over several hours of the percentage and the velocity of motile human spermatozoa whether incubated in seminal plasma or in synthetic media. The rate of decline during the 8-hrs incubation in seminal plasma is similar to that previously observed (Makler et al., 1979), but since it is also identical in all media, this effect could be attributed directly to the spermatozoa, i.e. it would be an indication of spermatozoal senescence. However, the composition of a medium does influence the actual percentage and velocity of motile spermatozoa. Harvey (1960) found a smaller decrease in human sperm velocities when diluted in saline or glucose phosphate solution compared to seminal plasma, and Freund and Wiederman (1966) observed a slower decline in the percentage of motile spermatozoa in media containing calcium, magnesium and glucose. Lopata et al. (1976) found a good survival over 24 hours of migrated spermatozoa in a diluent having an electrolyte composition similar to that of tubal fluid and containing albumin. While Locke's, Tyrode's and $B_{2}$ media contain glucose and calcium, Locke's, which induces a weaker stimulation of sperm velocity, has neither magnesium nor phosphate ions.

The beneficial influence of albumin on sperm motility has been demonstrated in the bull by Bredderman and Foote (1971) and in human spermatozoa by Lindholmer and Eliasson (1974). However, a statistically indistinguable stimulation of human sperm motility was obtained in the present study by Tyrode's solution which does not contain any albumin (fig. 1 a-b). $B_{2}$ medium, which has an electrolyte composition similar to bovine tubal fluid and contains albumin, was found to be the optimal medium for the survival and maintenance of motility in human spermatozoa in vitro.

A critical role of medium composition on sperm motility (probably acting via cell metabolism) is confirmed by the absence of any changes in vitality of the spermatozoa and the ability of immobile spermatozoa to "re-mobilize " when the necessary substrates (included in $B_{2}$ medium) are added to the medium (fig. 2 ).

The choice of the incubation temperature is also important for the maintenance of sperm motility. After one hour there is no modification in the percentage of motile spermatozoa at any temperature, although the velocity is 
temperature-dependent, as reported by Milligan et al. (1978). After 4 hrs, cooling from room to refrigerator temperature was found to be critical as previously shown for human (Fredricsson and Kinnari, 1979) and bovine (Freund and Wiederman, 1966) spermatozoa, although at that time, there was no difference in percentage motility at 20 or $37^{\circ} \mathrm{C}$. After longer periods of incubation, motility was best maintained when spermatozoa were kept at $20^{\circ} \mathrm{C}$, as has been observed by many authors.

A possible role of bacterial growth on sperm survival has been reported by Appel and Evans (1978). Since $B_{2}$ medium contains penicillin and streptomycin (see table 1), the higher velocities in the first hours at $37^{\circ} \mathrm{C}$, followed by a rapid drop later on, was more probably due to the exhaustion of metabolic substrates. Indeed, Hammerstedt et al. (1980) have shown that glucose consumption is multiplied 16-fold when incubation temperature is increased from 18 to $37^{\circ} \mathrm{C}$. Other factors such as exposure to light may also influence spermatozoal survival (Hamner and Williams, 1964).

For current practice a good motility can be maintained for several hours at room temperature when the spermatozoa are diluted in a suitable medium.

Reçu en mai 1981.

Accepté en août 1981.

Acknowledgements. - The authors would like to thank $\mathrm{Dr}$ A. Spira for his statistical advice, Dr D. Mortimer for valuable discussions and assistance with the translation, and Mrs D. Blanquart for typing the manuscript.

Résumé. L'influence de différentes conditions d'incubation in vitro et de différents milieux synthétiques sur la mobilité des spermatozoïdes humains a été testée. Le pourcentage de formes mobiles et la vitesse des spermatozoïdes ont été mesurés objectivement par vélocimétrie laser doppler. La vitalité a été déterminée par coloration fluorescente.

La centrifugation du sperme (dilué $1: 1$ avec du Tyrode) à 500, 800, 1800 et $2500 \times g$ a permis une sédimentation presque complète des spermatozoïdes. Après resuspension du culot dans une solution de Tyrode, la mobilité des spermatozoïdes n'a pas été significativement modifiée par rapport à celle mesurée dans le liquide séminal.

Le pourcentage de spermatozoïdes mobiles (mesuré à $37^{\circ} \mathrm{C}$ ) remis en suspension pendant $8 \mathrm{~h}$ à $20^{\circ} \mathrm{C}$ dans le Tyrode et le milieu $B_{2}$ a évolué de la même façon que dans le liquide séminal. Par contre, dans le Locke et le PBS, le pourcentage de spermatozoïdes mobiles a été significativement plus faible que dans le liquide séminal. La vitesse instantanée modale des spermatozoïdes $\left(V_{c}\right)$ (mesurée à $37^{\circ} \mathrm{C}$ ) remis en suspension pendant $8 \mathrm{~h}$ à $20^{\circ} \mathrm{C}$ dans le Locke, le Tyrode et le milieu $\mathrm{B}_{2}$ a augmenté significativement par rapport à celle des spermatozoïdes remis en suspension dans le liquide séminal. Dans le PBS les spermatozoïdes ont une vitesse plus faible que dans le liquide séminal, mais la différence n'est pas significative. Cependant les taux de décroissance des pourcentages de spermatozoïdes mobiles et de leurs vitesses sont semblables quels que soient les quatre milieux synthétiques ou le plasma séminal.

Aucune modification significative de la vitalité n'a été observée quel que soit le milieu utilisé pendant une période d'incubation de $8 \mathrm{~h}$ à $20^{\circ} \mathrm{C}$.

Lorsque les spermatozoïdes ont été incubées à $37^{\circ} \mathrm{C}$, le pourcentage de formes mobiles et leur vitesse dont diminué rapidement après $4 \mathrm{~h}$ d'incubation. Les spermatozoïdes soumis à une température de $4^{\circ} \mathrm{C}$ pendant $1 \mathrm{~h}$ n'ont pas subi de diminution significative de leur mobilité ; par contre une exposition prolongée à $4^{\circ} \mathrm{C}$ a réduit considérablement le pourcentage de formes mobiles et leur vitesse. 
La décroissance de la vitalité est lente et uniforme au cours des incubations à 4,20 , $37^{\circ} \mathrm{C}$ pendant $10 \mathrm{~h}$. La meilleure vitalité a été observée à $20^{\circ} \mathrm{C}$ et la moins bonne à $4^{\circ} \mathrm{C}$, cependant les différences $n^{\prime}$ ont pas été significatives quelles que soient la température et la durée d'incubation.

\section{References}

ALLOUCH P., 1980. Viscosity measurements of human semen (personal communication).

APPEL R. A., EVANS P. R., 1978. The effect of temperature on sperm motility II. Is bacterial growth a factor ? Fertil. Steril., 30, 436-438.

BENEDICT R. C., SCHUMAKER V. N., DAVIES R. E., 1967. The buoyant density of bovine and rabbit spermatozoa. J. Reprod. Fert., 13, 237-249.

BREDDERMAN P. J., FOOTE R. H., 1971. Factors stabilizing bull sperm cell volume and prolonging motility at high dilution, Exp. Cell Res., 66, 458-464.

DAVID G., BISSON J. P., CZYGLICK F., JOUANNET P., GERNIGON C., 1975. Anomalies morphologiques du spermatozö̈de humain. I. Propositions pour un système de classification. J. Gyn. Obstr. Biol. Repr., 4, suppl. 1, 17-36.

DUBOIS M., JOUANNET P., BERGE P., VOLOCHINE B., SERRES C., DAVID G., 1975. Méthode et appareillage de mesure objective de la mobilité des spermatozoïdes humains. Ann. Phys. Biol. Méd., 9, 19-41.

ELIASSON R., 1977. Semen analysis and laboratory workup, 169-188. In COCKETT A. T. K., URRY R. L., Male infertility, workup, treatment and research, Grune \& Stratton, New York.

FESTENSTEIN H., HALIM K., ARNAIZ-VILLENA A., 1978. HLA antigens on human spermatozoa, 11-16. In COHEN J., HENDRY W. E., Spermatozoa, antibodies and infertility, Blackwell Sci. Publ., London.

FREDRICSSON B., KINNARI S., 1979. Vitality and morphology of human spermatozoa studies on the resistance to storage and centrifugation and on the removal of dead spermatozoa. Andrologia, 11, 135-141.

FREUND M., WIEDERMAN J., 1966. Factors affecting the dilution freezing and storage of human semen. J. Reprod. Fert., 11, 1-17.

HAMMERSTEDT R. H., HAY S. R., 1980. Effect of incubation temperature on motility and CAMP content of bovine sperm. Arch. Biochem. Biophys., 199, 427-437.

HAMNER C. E., WILLIAMS W. L., 1964. The effect of light on the respiration of spermatozoa. Biochem. biophys. Res. Commun., 5, 316-320.

HARVEY C., 1960. The speed of human spermatozoa and the effect on it of various diluents, with some preliminary observations on clinical material. J. Reprod. Fert., 1, 84-95.

KANWAR K. C., YANAGIMACHI R., LOPATA A., 1979.' Effects of human seminal plasma on fertilizing capacity of human spermatozoa. Fertil. Steril., 31, 321-327.

LAPLANCHE A., 1978. Variabilité intra-individuelle du sperme humain pour la numération, le volume total et le nombre total de spermatozoïdes. Rôle du délai de continence. Mém. D.E.R.B.H., Unité Rech. Statit. INSERM 94800 Villejuif-France.

LINDHOLMER C., ELIASSON R., 1974. The effects of albumin, magnesium and zinc on human sperm survival in different fractions of split ejaculate. Fertil. Steril., 25, 424-430.

LOPATA A., PATULLO M. J., CHANG A., JAMES B., 1976. A method for collecting motile spermatozoa from human semen. Fertil. Steril., 27, 677-684.

LOPATA A., BROWN J. B., LEETON J. F., TALBOT J. M., WOOD C., 1978. In vitro fertilization of preovulatory ovocytes and embryo transfer in infertile patients treated with clomiphene and human chorionic gonadotropin. Fertil. Steril., 30, 27-35.

MAKLER A., ZAIDISE I., PALDI E., BRANDES J. M., 1979. Factors affecting sperm motility. I. In vitro change in motility with time after ejaculation. Fertil. Steril., 31, 147-154.

MÉNÉZO Y., 1976. Milieu synthétique pour la survie et la maturation des gamètes et pour la culture de l'œuf fécondé. C. R. Acad. Sci. Paris, Sér. D., 282, 1967-1970. 
MILLIGAN M. P., HARRIS S. J., DENNIS K. J., 1978. The effect of temperature on the velocity of human spermatozoa as measured by time-lapse photography. Fertil. Steril., 30 , 592-594.

OVERSTREET J. W., YANAGIMACHI R., KATZ D. F., HAYASHI K., HANSON F. W., 1980. Penetration of human spermatozoa into the human zona pellucida and the zona free hamster egg : a study of fertile donors and infertile patients. Fertil. Steril., 33, 534-542.

PETERSON R. N., FREUND M., 1969. Glycolysis by washed suspensions of human spermatozoa. Effects of substrate, substrate concentration and changes in medium composition on the rate of glycolysis. Biol. Reprod., 1, 238-246.

TREDWAY D. R., SETTLAGE D. F., NAKAMURA R. M., MOTOSHIMA M., UMEZAKI G. U., MISHELL D. R., 1975. Significative of timing for the poscoital evaluation of cervical mucus. Am. J. Obstet. Gynec., 121, 387-393.

YANAGIMACHI R., YANAGIMACHI H., ROGERS B. J., 1976. The use of zona-free animal ova as a test-system for the assessment of fertilizing capacity of human spermatozoa. Biol. Reprod., 15, 471-476. 